\title{
RESEARCH OF DETERMINANTS OF NON-PERFORMING LOANS OF THE BANKING SECTOR OF SERBIA
}

\author{
Nela Milišić \\ Provincial Secretariat for higher education and scientific research, \\ Novi Sad, Republic of Serbia
}

Željko Račić

Novi Sad School of Business, Novi Sad, Republic of Serbia

\begin{abstract}
The aim of this paper is to identify and analyze important internal and macroeconomic factors that determine the level of non-performing loans in the domestic banking sector thus contributing to the process of managing banks' credit risk. The research is based on the application of linear regression model (OLS). In accordance with the results, we have concluded that the growth in lending activities and the concentration of the five largest banks contributed to the increase in the share of non-performing loans in the credit portfolio of the banking sector.
\end{abstract}

Key words: bank's lending activity, non-performing loans, credit risk management, linear regression model (OLS), concentration of banking sector, HHI index.

JEL Classification: G11, G21

\section{ISTRAŽIVANJE DETERMINANTI PROBLEMATIČNIH KREDITA BANKARSKOG SEKTORA SRBIJE}

Sažetak: Cilj rada je da identifikuje i analizira važne interne i makroekonomske faktore koji determinišu nivo problematičnih kredita u domaćem bankarskom sektoru, pružajući tako doprinos procesu upravljanja kreditnim rizikom banaka. Istraživanje je bazirano na primeni linearnog regresionog modela (OLS). Na osnovu rezultata istraživanja, došli smo do zaključka da rast kreditne aktivnosti domaćih banaka $i$ rast koncentracije pet najvećih banaka doprinose povećanju udela problematičnih kredita u kreditnom portfoliju bankarskog sektora Srbije.

*nela.milisic@gmail.com 
24 RESEARCH OF DETERMINANTS OF NON-PERFORMING LOANS OF THE BANKING SECTOR OF SERBIA

Kljućne reči: kreditna aktivnost banaka, problematični krediti, upravljanje kreditnim rizikom, linearni regresioni model (OLS), koncentracija bankarskog sektora, HHI indeks.

\section{INTRODUCTION}

One of the most important characteristics of contemporary world markets is dynamism. Frequent market changes cause different types of crises that have a negative impact on performance of financial institutions. Commercial banks are particularly exposed to this negative impact because their asset portfolio in most cases contains a significant percentage of long-term loans. An important consequence of each crisis is an increase in non-performing loans in banks' portfolios caused by a decrease in the ability of borrowers to pay matured credit obligations. Bearing this in mind, risk managers constantly make the effort to reduce the level of non-performing loans in order to protect banks' liquidity and solvency. The current trend of financial consolidation as well as the growth of economic activity in the Republic of Serbia caused a decrease in non-performing loans in total banks' loan portfolio.

The aim of this paper is to identify significant bank-specific and macroeconomic factors which determine the level of non-performing loans in banks' loan portfolios, and to contribute to the process of banks' credit risk management in the Republic of Serbia. The hypothesis of the existence of statistically significant bank-specific and macroeconomic factors which determine the level of non-performing loans was tested using Ordinary least squares (OLS) regression model. The results and conclusions of the research are based on the data from "Banking Sector-Quarter and Annual reports" published by National Bank of Serbia. (https://www.nbs.rs).

The paper contains six parts. After Introduction and Literature review, the third part describes Specification of econometric model used in the research. Fourth and fifth part analyze the results of the research, while the last part captures conclusions of the paper.

\section{LITERATURE REVIEW}

A number of scientific papers have provided a definition of significant determinants of non-performing loans and analyzed their influence on overall banks' performance. As we mentioned before, determinants of nonperforming loans can be described as bank-specific and macroeconomic determinants. Bank-specific determinants are caused by internal functions 
and activities and they can be controlled by improving various aspects of banks' business process (Partovi and Matousek, 2019). On the other hand, macroeconomic factors are caused by the external environment and they are not under banks' control (Ozili, 2019). Ekanayake and Azeez (2015) concluded that the level of non-performing loans depends on a few bankspecific factors. They found a positive correlation between the level of nonperforming loans and the level of bank's efficiency and loan to asset ratio. Also, Curak, Pepur and Poposki (2013) concluded that the size of banks as well as their efficiency and solvency determine the level of non-performing loans of banks that operate in Southern Europe. Goldstein and Turner (1996) found that the level of non-performing loans depends on many macroeconomic factors such as economic downturns, macroeconomic volatility, high interest rates, deteriorating trading conditions and so on. Boye (2007) found that real interest rates and unemployment rate are positively correlated with non-performing loans of banks that operate in Nordic banking system. Louzis, Vouldis and Metaxas (2010) found that unemployment with one-year lag is the most important determinant of nonperforming loans. Cifter (2011) concluded in his research that the growth of concentration in the banking sector contributes to the growth of nonperforming loans. Jimenez and Saurina (2006), Das and Ghosh (2007) and Warue (2013) estimated that one of the main causes of the growth of nonperforming loans is the decline in economic activity. However, there are many studies which suggest that the growth of economic activity causes an increase in the share of non-performing loans. Roi, Dei and Bhovmik (2014) concluded that inflation and the rise of the banks' active interest rates result in an increase in the level of non-performing loans.

Bearing in mind the majority of the statistically significant determinants of non-performing loans identified in previous researches, we constructed an OLS regression model. The specification of the model is presented below.

\section{SPECIFICATION OF ECONOMETRIC MODEL}

OLS regression model used in this research can be illustrated by the following equation:

$$
\begin{aligned}
& n p l_{i}=\alpha+\beta_{1} \text { kred_akt }_{i}+\beta_{2} \text { rast_kred }_{i}+\beta_{3} \text { kre_dep }_{i}+\beta_{4} \text { efi } k_{i} \\
& +\beta_{5} \operatorname{solv}_{i}+\beta_{6} g d p_{i}+\beta_{7} \text { konc }_{i}+u_{i}
\end{aligned}
$$

where,

$\alpha$ - denotes intercept,

$\beta_{1, \ldots,} \beta_{7^{-}}$denote estimated regression coefficients,

$\mathrm{u}_{\mathrm{i}}$ - denotes residuals of the model.

SCHOOL OF BUSINESS, 2/2019, 23-34 
26 | RESEARCH OF DETERMINANTS OF NON-PERFORMING LOANS OF THE BANKING SECTOR OF SERBIA

Main characteristics of variables considered in the research are shown in the Table 1.

Table 1

Variables used in the regression OLS model

\begin{tabular}{llll}
\hline \multicolumn{1}{c}{ Explanation } & Variable & Average & $\begin{array}{l}\text { Standard } \\
\text { Deviation }\end{array}$ \\
\hline Non-performing Loans to Total Loans & npl & 18 & 5.248 \\
Total Loans to Total Asset & kred_akt & 0.592 & 0.029 \\
Growth rate of Total Loans & rast_kred & 0.010 & 0.034 \\
Loans to Deposit Ratio & kre_dep & 0.912 & 0.059 \\
Bank's performance efficiency (ROA) & efik & 0.013 & 0.007 \\
Capital adequacy Ratio (solvency) & solv & 0.213 & 0.011 \\
Growth Rate of GDP & gdp & 0.005 & 0.010 \\
Ln (HHI index)- 5 biggest banks & konc & 6.438 & 0.076 \\
\hline
\end{tabular}

Note. The calculation made by the authors.

Total Loans to Total Asset ratio (kred_akt): This ratio shows how focused Serbian banks are on lending activities and how much they base profitability on interest income. Growth of lending activities confirms more aggressive banks' lending policy which may increase level of non-performing loans. Bearing this in mind we expect that total loans to total asset ratio will be positively related with the level of non-performing loans (positive value of $\beta_{1}$ coefficient).

Growth rate of Total Loans (rast_kred): Variations in growth rate of total loans show changes in banks' credit standards. In order to increase market share or to improve short term business performance banks often lend riskier loans, which can result in an increase in the share of non-performing loans in the total credit portfolio. In accordance with that, we expect a positive value of the $\beta 2$ coefficient.

Loan to deposit LTD ratio (kre_dep): The LTD ratio shows to what extent domestic banks base their loan activities on deposit sources. A rise in the value of LTD ratio indicates the existence of credit expansion, which is often connected with the placement of riskier loans. Bearing this in mind we expect that LTD ratio will be positively related with the level of nonperforming loans (positive value of $\beta_{3}$ coefficient).

Bank's performance efficiency (efik): In this research, return on assets of domestic banks (ROA) was considered an indicator of bank's performance efficiency. The managers who operate in more-efficient banks are under less pressure to earn extra profit, which results in higher quality loans and lower 
exposure to credit risk. On the other hand, managers who operate in lessefficient banks are constantly under pressure to generate higher profits, which often forces them to decrease credit standards (we expect a negative value of $\beta 4$ coefficient).

Solvency (solv): Capital adequacy ratio, calculated in accordance with Basel standards, was considered an indicator of bank's solvency. Taking into account the fact that the methodology for calculating the capital adequacy ratio is based on the assessment of credit risk exposure, we can conclude that the quality of bank's loans is negatively correlated with capital requirements. That means we can expect a negative value of the regression coefficient $\beta 5$.

Growth Rate of GDP $(g d p)$ : GDP as a basic macroeconomic variable shows the level of economic activity. Considering the downward trend in interest rates in the domestic market as well as the assumption that the growth of economic activity influences the growth of the borrower's creditworthiness, we can expect a negative value of the regression coefficient $\beta 6$.

Concentration of the five largest banks (konc): As we know, an increase of the concentration in the banking sector threatens the operations of banks with a smaller market share. Bearing this in mind, we expect a positive value of the regression coefficient $\beta 7$.

\section{RESULTS OF THE RESEARCH}

The results of the application of the OLS regression model are presented in Table 2.

Table 2

Results of OLS model estimation

\begin{tabular}{lrrr}
$\begin{array}{l}\text { Number of obs }=23 \\
\mathrm{~F}(7,15)=10.30\end{array}$ & \multicolumn{2}{l}{$\begin{array}{l}\text { Prob }>\mathrm{F}=0.0001 \\
\text { R-squared }=0.8278\end{array}$} & \multicolumn{2}{c}{$\begin{array}{l}\text { Adj R-squared }=0.7474 \\
\text { Root MSE }=2.6375\end{array}$} \\
\hline$n p l$ & Coef. & $\mathbf{T}$ & $\mathbf{p}>[\mathbf{t}]$ \\
\hline kred_akt & -111.8047 & -2.36 & $0.032^{* *}$ \\
rast_kred & 20.4308 & 0.95 & 0.356 \\
kre_dep & 85.3712 & 2.57 & $0.021^{* *}$ \\
efik & -167.8221 & -1.21 & 0.244 \\
solv & -156.4719 & -1.22 & 0.241 \\
konc & 47.5480 & 2.26 & $0.039^{* *}$ \\
gdp & -8.9271 & -0.11 & 0.911 \\
ccons & -264.286 & -1.71 & 0.107 \\
\hline
\end{tabular}

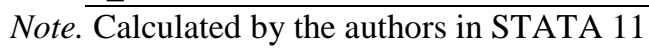


28 | RESEARCH OF DETERMINANTS OF NON-PERFORMING LOANS OF THE BANKING SECTOR OF SERBIA

In order to provide the best linear unbiased estimates of the regression coefficients, we checked the fulfillment of the standard assumptions of the OLS models. The details about standard assumptions of linear regression models are presented in Table 3.

Table 3

Standard assumptions of OLS linear regression model

\begin{tabular}{|c|c|c|}
\hline Notation & Meaning & Note \\
\hline 1. $\mathrm{E}\left(u_{i}\right)=0$ & Average value of residuals is zero & it is not checked \\
\hline 2. $\operatorname{Var}\left(u_{i}\right)=\sigma^{2}$ & $\begin{array}{l}\text { The variance of the residuals is } \\
\text { constant }\end{array}$ & homoskedasticity \\
\hline 3. $\operatorname{Cov}\left(u_{i}, x_{i}\right)=0$ & $\begin{array}{l}\text { There is no linear relationship } \\
\text { between residues and } x\end{array}$ & it is not checked \\
\hline 4. $u_{i} \sim \mathrm{N}\left(0, \sigma^{2}\right)$ & $\begin{array}{l}\text { Residuals have a normal } \\
\text { distribution }\end{array}$ & $\begin{array}{l}\text { it is not checked } \\
\text { if } n>30\end{array}$ \\
\hline $5 . \operatorname{Cov}\left(u_{i}, u_{j}\right)=0$ & $\begin{array}{l}\text { Residuals don't depend on each } \\
\text { other }\end{array}$ & $\begin{array}{l}\text { absence of } \\
\text { autocorrelation }\end{array}$ \\
\hline 6. Multicollinearity & $\begin{array}{l}\text { Independent variables are not } \\
\text { correlated with each other }\end{array}$ & $\begin{array}{l}\text { absence of } \\
\text { multicollinearity }\end{array}$ \\
\hline
\end{tabular}

Note. Retrived from Račić, Ž. (2013). Komparativna analiza izloženosti banaka riziku kamatne stope na primeru razvijenih finansijskih tržišta i finansijskog tržišta Republike Srbije. Beograd, Republika Srbija: Univerzitet Singidunum.

The presence of multicollinearity in the model was tested using the VIF test (Variance inflation factor). If the VIF values of the variables are about 10 and less, then the model is considered to have no multicollinearity.

Table 4

Results of the VIF test- checking existence of multicollinearity in the model

\begin{tabular}{ll}
\hline Variable & VIF \\
\hline kre_dep & 12.34 \\
Konc & 7.98 \\
kred_akt & 5.90 \\
Solv & 5.76 \\
Efik & 2.85 \\
Gdp & 1.92 \\
Rast_kred & 1.72 \\
\hline Average VIF value & $\mathbf{5 . 5 0}$ \\
\hline
\end{tabular}

Note. Calculated by the authors in STATA 11.

Table 4 shows that the average VIF value of the independent variables is 5.50. In accordance with this value, we reject the hypothesis of the existence 
of multicollinearity, which means there is no significant linear dependence between explanatory variables in the model. Bearing in mind the fact that the research is based on 23 observations, we checked the fulfillment of the assumption about the normality of the distribution of residuals. For this purpose, we used the Shapiro-Wilk W test, which tests the hypothesis about distribution normality. In accordance with the results of the test (Prob> $z=$ 0.842) we accepted the hypothesis about distribution normality of the residuals (Figure 1).

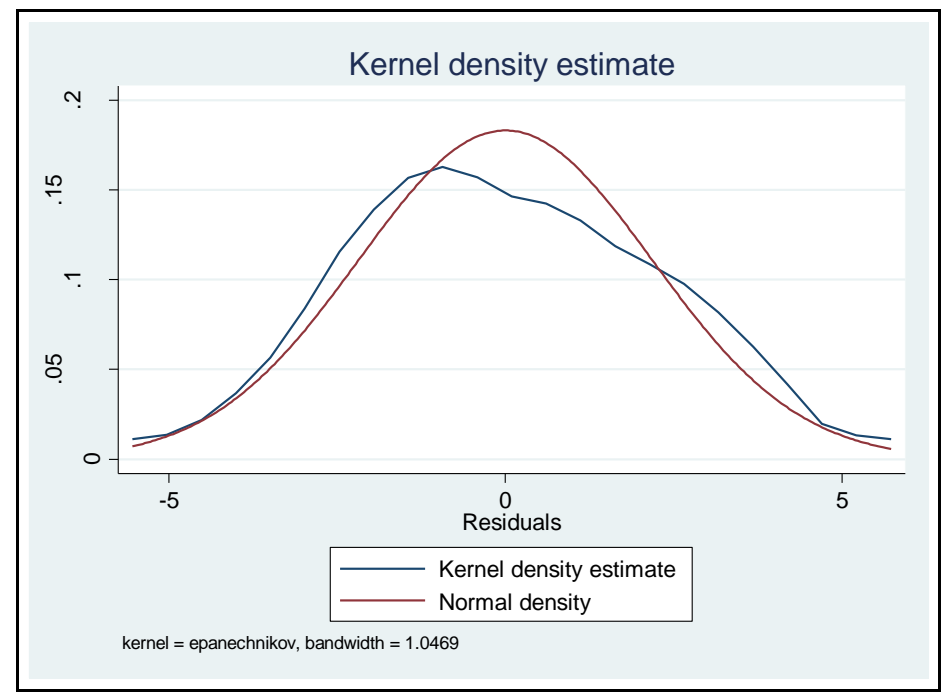

Figure 1. Distribution of the residuals

Note. STATA 11 output.

The presence of heteroskedasticity was tested by the Breusch-Pagan/Cook Weisberg test. The results of the test (Prob> chi2 $=0.049$ ) indicate presence of boundary heteroskedasticity in the model. The inhomogeneity of the residuals dispersion around their average value is shown in Figure 2.

The presence of heteroskedasticity in the model can reduce the reliability of the estimated regression coefficients. In order to obtain reliable and unbiased estimates we applied the Newey-West regression model which was developed in 1987 to reduce heteroskedasticity and autocorrelation of residuals in regression models (Newey and West, 1987). The results of implementation of Newey-West regression model are presented in Table 5. 
30 | RESEARCH OF DETERMINANTS OF NON-PERFORMING LOANS OF THE BANKING SECTOR OF SERBIA

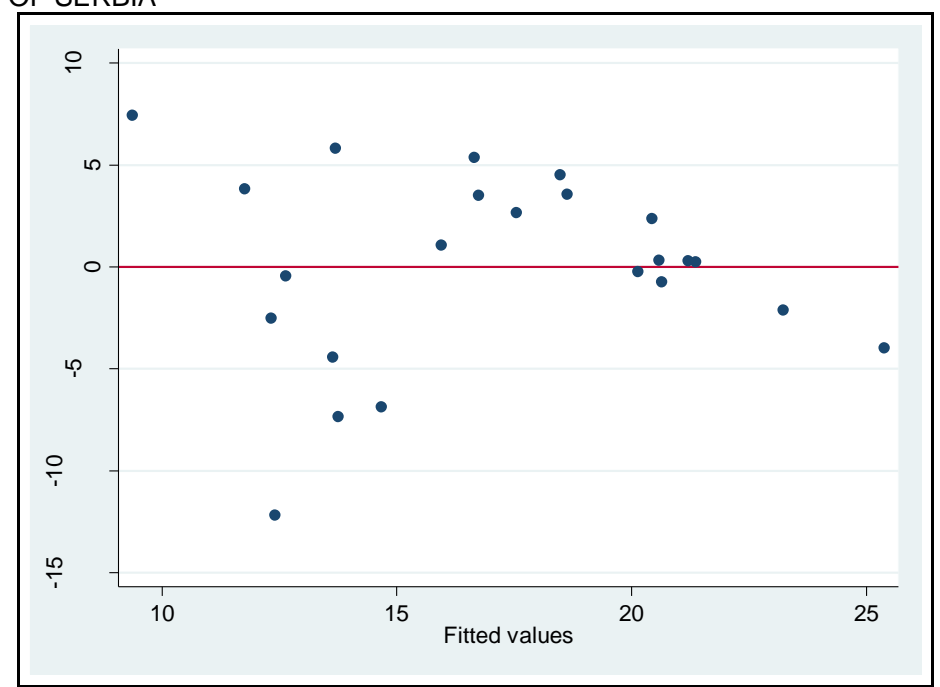

Figure 2. Residuals dispersion around the average value Note. STATA 11 output.

Table 5

The results of implementation of Newey-West regression model

\begin{tabular}{lrrr}
\hline $\begin{array}{l}\text { Regression with } \\
\text { standard errors } \\
\text { maximum lag: } 5\end{array}$ & & \multicolumn{2}{r}{$\begin{array}{r}\text { Number of obs }=23 \\
\mathrm{~F}(7,15)=9.39 \\
\text { Prob }>\mathrm{F}=0.0002\end{array}$} \\
\hline npl & Coef. & $\mathbf{T}$ & $\mathbf{p}>[\mathbf{t}]$ \\
kred_akt & -111.8047 & -1.79 & $0.093^{*}$ \\
rast_kred & 20.4308 & 1.84 & $0.086^{*}$ \\
kre_dep & 85.3712 & 2.68 & $0.017^{* *}$ \\
efik & -167.8221 & -1.68 & 0.113 \\
solv & -156.4719 & -0.83 & 0.419 \\
konc & 47.5480 & 2.78 & $0.014^{* *}$ \\
gdp & -8.9271 & -0.13 & 0.901 \\
cons & -264.286 & -2.22 & $0.042^{* *}$ \\
\hline
\end{tabular}

Note. Calculated by the authors in STATA 11.

Based on the value of the adjusted coefficient of determination (see Table 2), we have concluded that about $75 \%$ of the variations of non-performing loans are explained by variations of the analyzed independent variables. 


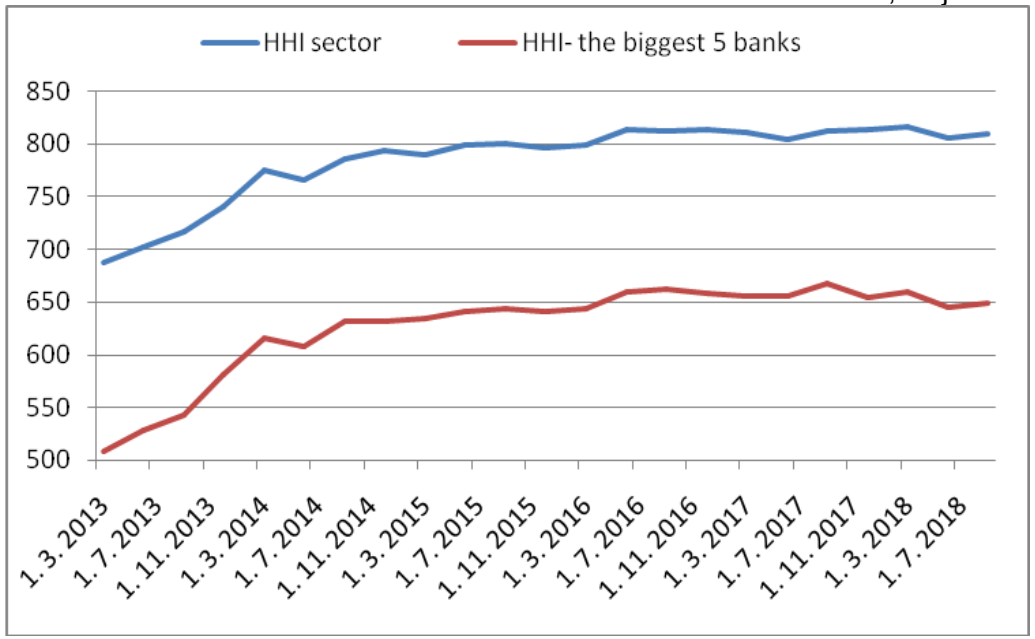

Figure 3. Comparative presentation of the values of HHI index of banking sector of Serbia and the values of HHI index of five largest domestic banks.

Note. Authors' calculation.

Variations of LTD ratio (kre_dep) as well as variations of concentration indicator (konc) have statistically significant effects on the non-performing loans, while marginal influence (statistical significance - 90\%) is achieved by the variations of growth rate of total loans (rast_kred).

\section{DISCUSSION AND ANALYSIS}

An increase in lending activity of domestic banks contributes to an increase in the share of non-performing loans in the banking sector's loan portfolio. It means that despite the downward trend in interest rates on the domestic financial market, credit users face problems with repayment of their credit obligations. Taking into account the high level of liquidity and the high level of capital adequacy ratio, we can conclude that domestic banks face an excess of credit potential. This situation indicates that at the moment too many banks are operating on domestic financial market compared to current market needs. Although the presence of a large number of banks contributes to the development of market competition, it is noticeable that the five largest banks have a large share in the total balance sheet of the sector (see Figure 3). The market share of the five largest banks supports the assessment that smaller domestic banks are in a subordinate position compared to larger competitors. This is also evidenced by the results of research which show that the growth of the concentration of the five largest banks contributes to the growth of the share of non-performing loans. Smaller domestic banks are predominantly focused on smaller, local markets because they have weaker 
32 | RESEARCH OF DETERMINANTS OF NON-PERFORMING LOANS OF THE BANKING SECTOR OF SERBIA

financial power compared to largest banks. The pressure on the interest income due to the decrease in interest rates on the domestic financial market, combined with the limited base of potential loan beneficiaries, forces smaller banks to decrease credit criteria. Smaller banks are engaging in riskier lending, putting at a lower level security that is reflected in clearly defined criteria, loan approval, modification, renewal and refinancing processes, as well as internal methodology conclusions that make the credit risk assessment of individual clients.

\section{CONCLUSION}

Two general conclusions can be drawn regarding the possibilities of reducing the share of problem loans in the domestic banking sector. First, it is necessary to make additional efforts to improve the business environment for domestic companies in order to increase their creditworthiness as well as demand for loans. Second, there is a need for redistribution of domestic banks' market share in the domestic financial market as evidenced by increasing acquisitions that do not jeopardize the level of competition, and which result in a reduction in the share of non-performing loans in the total loan portfolio.

\section{REFERENCES}

Azofra, V., \& Santamaría, M. (2011). Ownership, control, and pyramids in Spanish commercial banks. Journal of Banking \& Finance, 35(6), 1464-1476.

Boye, O. B. (2007). An analysis of banks' problem loans. Economic Bulletin, 2, 65-76.

Cifter, A. (2011). Bank concentration and non-performing loans in Central and Eastern European countries. Journal of business Economics and Management, 16(1), 117-137.

Ćurak, M., Pepur, S., \& Poposki, K. (2013). Determinants of non-performing loans - evidence from Southeastern European banking systems. Banks and Bank Systems, 8(1), 45-53.

Das, A., \& Ghosh, S (2007). Determinants of credit risk in Indian stateowned banks: An empirical investigation. Economic Issues, 12(2), 2746. 
Ekanayake \& Azeez. ( 2015). Determinants of non-performing loans in licensed commercial banks: evidence from Sri Lanka. Asian Economic and Financial Review, 5(6), 868-882.

Filipović, M., Avramović, V., \& Račić, Ž. (2016). Analiza nivoa koncentracije aktive u bankarskom sektoru Rebublike Srbije. Škola Biznisa, 2, 111-119.

Goldstein, M., \& Turner, P. (1996). Banking crises in emerging economies: origins and policy options. BIS economic papers, 46.

Iannotta, G., Nocera, G., \& Sironi, A. (2007). Ownership structure, risk and performance in the European banking industry. Journal of Banking and Finance, 31(7), 2127-2149.

Jimenez, G., \& Saurina J. (2006). Credit cycles, credit risk, and prudential regulation. International Journal of Central Banking, 2(2), 65-98.

Louzis, D. P., Vouldis, A. T., \& Metaxas, V.L. (2010), Macroeconomic and bank-specific determinants of non-performing loans in Greece: a comparative study of mortgage, business and consumer loan portfolios. Bank of Greece, Working Paper, No 118.

Narodna Banka Srbije

. https://www.nbs.rs/internet/latinica/55/55_4/index.html

Newey, W., \& West, K. (1987). A simple, positive semi- definite, heteroskedasticity and autocorelation consistent covariance matrix, Econometrica, 55(3), 703-708.

Ozili, P. (2019). Non-performing loans and financial development: new evidince. Journal of Risk Finance, 20(1), 59-81.

Partovi, E., \& Matousek, R. (2019). Bank efficiency and non-performing loans: Evidence from Turkey, Research in international Business and Finance, 48, 287-309.

Račić, Ž. (2013). Komparativna analiza izloženosti banaka riziku kamatne stope na primeru razvijenih finansijskih tržišta i finansijskog tržišta Republike Srbije (Doktorska disertacija). Beograd, Republika Srbija: Univerzitet Singidunum.

Račić, Ž., \& Barjaktarović, L. (2016). Analiza empirijskih determinant kreditnog rizika bankarskog sektora Republike Srbije. Bankarstvo, 45(4), 94-109.

Roy, S., Dey, P. K., \& Bhowmik, P. (2014). Non-Performing Loans in Private Commercial Banks of Bangladesh: Macro-Economic SCHOOL OF BUSINESS, 2/2019, 23-34 
34 | RESEARCH OF DETERMINANTS OF NON-PERFORMING LOANS OF THE BANKING SECTOR OF SERBIA

Determinants and Impacts. The Jahangirnagar Journal of Business Studies, 4(1), 47-57.

Warue, B. N. (2013). The Effects of Bank Specific and Macroeconomic Factors on Nonperforming Loans in Commercial Banks in Kenya: A Comparative Panel Data Analysis. Advances in Management \& Applied Economics, 3(2), 135-164.

Delivered: 25.11.2019.

Accepted: 17.12.2019. 